\title{
Exploitation and Utilization of College Art Education Resources Based on Carrying Forward National Culture
}

\author{
Lv Zhengzheng \\ Tonghua Normal University, Tonghua, Jilin, 134002
}

\begin{abstract}
Promoting the development and utilization of art resources in colleges and universities is an important requirement to enhance the cohesion of the Chinese nation and to realize the great rejuvenation of the Chinese nation. At present, there are many problems in art education in colleges and universities, like single teaching methods and few teaching resources. The development of art education in colleges and universities should attach importance to the development and utilization of educational resources, carry forward the traditional culture of the Chinese nation, and enrich and improve the content of art education in colleges and universities.

Keywords: national culture; college art education; resources exploitation and utilization

Art education is an important part of quality education in our country and plays an important role in promoting students' all-round development. The development and utilization of arts education resources in colleges and universities based on the promotion of national culture, which can not only promote the development of our national culture, but also inherit and carry forward our excellent traditional culture, to enhance students' charisma, cultivate sentiment and promote the development of art education[1].
\end{abstract}




\section{1, the status quo and existing problems of art education in Chinese colleges and universities}

With the national and government attention to art education, many colleges and universities in China have carried out art education, but in the process of art education, many universities have encountered more or less problems, such as unclear art education management responsibilities imbalance supply and demand of some institutions of higher learning art education teacher. In addition, the power of full-time teachers can not be effectively protected, while the part-time job is not perfect, which lack of supervision and management. There is undocumented posts phenomenon that teachers do not have the appropriate teaching qualifications. Some schools of art education courses are not comprehensive knowledge, and their teaching content and teaching methods are too single, which can not meet the students' pursuit of knowledge and desire. In addition to the university itself, the level of ideological consciousness of teachers also affect the effect of art education [2]. Some teachers like to purse the diversity of teaching methods, while the practical content of the curriculum is poor; some teachers teaching structure is too loose. In addition to the above problems, the current utilitarian university, the pursuit of pragmatism, leading to the university did not really realize the importance of art education, so students' artistic accomplishment becomes empty talk.

\section{2, the necessity of carrying forward the national culture in art education}

National culture is relative to foreign culture, in the development and utilization of university art education resources, carrying forward the national culture is the return of the Chinese national subject consciousness. Cultivating the Chinese national subject consciousness and increasing national cohesion are the important requirement of great rejuvenation of the Chinese nation, the bounden duty of the higher education in our country and the principle of the development and utilization of the art education resources in colleges and universities. In his speech, Comrade Jiang Zemin once said: If a nation is not inspired by the national spirit and lacks noble national character and ethical aspirations, it will not be able to base itself on the national forest of the world. Our people will strengthen the spiritual strength of the Chinese nation and enrich the spirit of the Chinese nation. According to the relevant institutions of China's college students art quality survey, $90 \%$ of the respondents said that China's traditional culture do not understand or know very little, $95 \%$ of the students failed to master the national painting, dance, music and other art. In-depth survey of students found that more than $60 \%$ of students said they did not have enough time to learn the national culture, there are $10 \%$ of students said that national art is out of date, and can not adapt to the development of modern society, there are some students said that the national culture and the arts and the national spirit is not in line with 
modern society's aesthetic requirements. From these findings can be found that the contemporary college students lack and lose aesthetic sense of popular culture while the pursuit of individual development has been deeply integrated into the hearts of the people, so the contemporary college students' ideas, national consciousness and value orientation have a serious impact on a serious national aesthetic awareness, which will not conducive to the inheritance and development of our national culture, the Chinese nation in the historical and cultural heritage of the precious wealth left unanswered after the crisis. If students can not understand and master our excellent traditional culture, will lead to lacking of national culture and history.

Therefore, the development and utilization of arts education resources in colleges and universities must take the promotion of national culture as the starting point, make full use of our outstanding national cultural resources, emphasize the subjectivity of national culture, extend the vitality of our outstanding national culture, recognize art education from the national character unique charm, so that contemporary students through art education can enhance Chinese national pride, enhance national self-esteem and self-confidence, to establish national consciousness. Moreover, individual as a unit can assume the responsibility of national cultural heritage and protection. Guiding students to get a sense of belonging and tracing the roots of traditional culture are good way to understand and master the history of the Chinese nation, with a strong sense of national pride [3].

\section{3, the advantages development and utilization of art education resources}

Chinese culture has a long history, has thousands of years of cultural precipitation, has accumulated rich cultural resources, and has formed the indomitable spirit of the national spirit and rich artistic characteristics, so that it provides a wide range of cultural foundation for the development and utilization of arts education resources in colleges and universities. Education resources development and utilization has a significant advantage.

China's ethnic groups are diverse, and after long-term development, each ethnic group has formed a unique cultural type, so that artistic resources are very rich, which can arouse the attention of different students to stimulate students interest in art learning. Through the appreciation of art, students can have a comprehensive understanding of Chinese cultural traditions, geographical environment and ecology to learn different national life styles and characteristics of art, and then have a strong interest in art education. In addition, the culture and art of different regions and different nationalities have their unique advantages, which can provide textbooks for different types of art, and promote the comprehensive development of art education in colleges and universities.

Different living environments, lifestyles and natural forms, form a different art form. Each form of art is in a different way to show the nation's artistic 
characteristics. The central region is the origin of Chinese Han culture, is the seat of the Chinese nation's main culture, has a wealth of artistic resources and forms of expression. In addition to the central region, ethnic minorities have their own unique cultural forms, such as the Zhuang people in dance, music, poetry and other aspects of congenital advantages, their artistic forms rich and varied, including music, folk songs, songs, minor, situation set songs, such as the festival song, drink songs, prayer songs, crying songs and so on. Dance in picking tea dance, hydrangea dance, pole dance, shrimp dance, division dance, etc. [4]. In addition, the art includes wallpaper painting, costumes, Zhuang Jin, architecture, and other types of art, has a long history and culture, greatly enriched the traditional Chinese painting. The study of national culture not only can improve the students' aesthetic ability, but also can improve the students' understanding of Chinese culture and history.

The national culture belongs to the world intangible cultural heritage. It is the inheritance of the intangible cultural heritage to the study and development of the national culture by the college art education. Through the university art education, the students can pay more attention to the importance of humanity, pursuit and art classics, so cultural ideas inherited. The continuation of national culture is fundamental to promote art through the education of members of society to master the national art. Art education in colleges and universities can make up for the shortcomings of higher education to stimulate students interest in learning the national culture, to maintain the continuity of national cultural vitality, and integrate the national consciousness into each person's life.

\section{4 the value of the development of college art education resources}

Good curriculum structure, the effective integration of resources can improve the efficiency of classroom teaching and get better results. The absence of art education resources will result in the disappearance of art courses. Similarly, the lack of support of art curriculum resources will not enable art education to achieve the desired goals. Once the resources of art education in universities can be exploited, it will broaden the scope of art education resources, enhance the quality of art education, enrich the content of art education, and make the art education resources more and more important. At the same time, improving the utilization rate of arts curriculum resources and ensuring the effectiveness and practicability of college art education curriculum resources.

In the development and utilization of art education resources in colleges and universities, teaching resources mostly originate from the students themselves, and are closely related to the students' learning. Whether from the perspective of the performance of art education resources, or from the perspective of curriculum content, art resources can stimulate students to carry out the interest of art education, students' thinking ability, to promote the overall development of students, to enhance the sense of smell and art. In the process of art education. 
Teachers should pay more attention to students' subjectivity, enhance students' learning initiative, strengthen communication and exchange with students, understand and grasp the actual situation of different students, facilitate targeted teaching and guide students to participate in art education process, improving students' enthusiasm for learning.

In the course of developing and utilizing the resources of art education in colleges and universities, teachers should change their teaching methods as the leader of the teaching process. In the process of teaching, they should update their teaching ideas and improve their teaching skills. At the same time, teachers must continue to receive relevant training, broaden the teaching knowledge, improve their knowledge structure, timely pay attention to the latest knowledge of art and subject development, improve their teaching skills with professional knowledge to make up for teaching According to the characteristics of different disciplines, teachers should grasp the actual needs of the art curriculum, excavate the knowledge in the art course, and timely reflect on their own teaching process, build a complete feedback system, timely feedback on the students' knowledge acceptance and teaching effect to enhance their teaching level [5].

Fifth, suggestions on the development and utilization of arts education resources in colleges and universities

In the study of mural art, colleges and universities can use the Yongle Palace, Dunhuang Mogao Grottoes as a mural teaching resources, as the second classroom for art learning of students who can experience the profound traditional Chinese culture with their own practical experience. In sculpture study, Yungang Grottoes, Longmen Grottoes and other sculpture can be used as a standard art teaching materials, which are representative of our sculpture, fully embodies the ancient Chinese sculpture the highest level of technology. Art education resources are around each person, and perhaps many people grew up in the art environment, but they never noticed the value of art education. To train students' ability to find, appreciate and create beauty is not just simply to teach students the artistic skills. One is good at discovering creating beauty is more important than a pair of simple description of the hands. China's art education to guide students in the actual experience of learning, is more emphasis on the learning process and methods to achieve the combination of emotion, value and skills.

Art education in colleges and universities can choose the source of life resources as art courses. For example, the mark can be seen everywhere in life, in the learning, teachers can choose some famous signs as a demonstration to the students about the meaning, role and value of the logo, as well as the enterprise concept behind so that students can analyze the success and failure of the logo case, which requires students to choose a topic and make use of existing knowledge to design a logo, so they can explain the reasons and the significance of representatives. Students can be completed independently, can also be free to group together to complete the learning tasks. In the process of art education, we should fully respect the students' understanding of life. In the practice of art, we can stimulate students' artistic creativity, and enhance students' understanding, love, and self-confidence of their works. 
Chinese culture has a long history, in the long history of evolution, China retained a lot of art treasures that are intangible wealth, which is the spirit of the Chinese nation. The university art education should be good at discovering and using our excellent national culture to carry out teaching activities. During the learning process, we should deepen the students' understanding of Chinese traditional culture, strengthen national self-esteem and self-confidence and protect and inherit our national culture. There are 56 nationalities in our country, these national culture have their own characteristics is important to our university art education with different levels, the students' artistic accomplishment and artistic taste. In the study of different cultures, it not only can enhance students' understanding of ethnic minorities, but also can promote national unity, which is conducive to building a socialist harmonious society [6].

Social and cultural resources can exercise the social practice skills of students. For example, in appreciation of art works, teachers can lead students to visit the local museums to enhance students' experience, so that students do not just confined to the understanding of things from books and drawings. Moreover, in the study of Chinese painting and other works of art, teachers and parents can lead students to take part in some art exhibitions and appreciate the works of art at close range so that students can have a direct dialogue with the works and enhance their personal experience. Teachers should listen to opinions and views from students, experience their learning ideas, and guide them to the longitudinal development of thinking. In the student art learning, teachers should promptly prompt students to learn from different angles, to make use of different ways to learn the art of expression, to enhance students' perception and self-perception of art, to stimulate students curiosity, exploration and creativity, and to deepen students' understanding of art.

\section{References:}

[1] Wang Xiaolei. Local Folk, Folk Art Resources in the Art of Design Education in the Development and Utilization [J]. Heilongjiang Higher Education Research, 2014,11: 119-121.

[2] Zhu Shue. Ningxia Regional Art Resources in the Development and Utilization of Art Education in Colleges and Universities [J]. Fine Arts, 2014,12: 175.

[3] Yuan Zhizheng. The Construction of Public Art Education Curriculum in Colleges and Universities from the Perspective of Regional Culture [J]. Art \& Tech, 2015,01: $28+49$. 